\title{
Sheep gastrointestinal helminthiasis in the Sertáo region of Paraíba State, Northeastern Brazil: prevalence and risk factors
}

\author{
Helmintoses gastrintestinais de ovinos no Sertão do Estado da Paraíba, Nordeste do Brasil: \\ prevalência e fatores de riscos
}

\author{
Vanessa Diniz Vieira'; Vinícius Longo Ribeiro Vilela ${ }^{2 *}$; Thais Ferreira Feitosa ${ }^{2}$; Ana Célia Rodrigues Athayde'; \\ Sérgio Santos Azevedo ${ }^{2}$; Diego Vagner de Oliveira Souto ${ }^{3}$; Gian Libânio da Silveira ${ }^{3}$; Lídio Ricardo Bezerra de Melo ${ }^{3}$ \\ ${ }^{1}$ Programa de Pós-Graduação em Zootecnia, Universidade Federal de Campina Grande - UFCG, Patos, PB, Brasil \\ ${ }^{2}$ Programa de Pós-Graduação em Medicina Veterinária, Universidade Federal de Campina Grande - UFCG, Patos, PB, Brasil \\ ${ }^{3}$ Unidade Acadêmica de Medicina Veterinária, Universidade Federal de Campina Grande - UFCG, Patos, PB, Brasil
}

Received May 31, 2014

Accepted August 4, 2014

\begin{abstract}
In this study, we aimed to establish the prevalence and risk factors relating to gastrointestinal helminthiasis, and to characterize the sanitary management practiced among sheep herds in the Sertão region of the state of Paraíba, northeastern Brazil, based on factors that condition the ways of controlling these parasites in these herds. The research was carried out between April and July 2012. We visited 54 farms, where fecal and blood samples were individually collected from 465 animals. On each farm, a questionnaire was applied to gather information on variables relating to potential risk factors. The prevalence of sheep gastrointestinal helminthiasis in the region was $75.9 \%$. At least one animal tested positive for this helminthiasis on 53 (98.1\%) of the 54 farms evaluated. The eggs per gram of feces (EPG) analysis showed the following infection burdens: $51.8 \%$ with mild infection, $27.1 \%$ moderate infection, $9.9 \%$ heavy infection and $11.2 \%$ fatal infection. Among the sheep farms visited, anthelmintics were used on $81.5 \%(\mathrm{p}<0.05)$. The most relevant risk factor in this study was the farm area, because it defines the area available for grazing animals. Properties with many animals and little pasture area, which are the most abundant type in the Sertão region of Paraíba, tend to have high prevalence of gastrointestinal helminthiasis, because the animals are more prone to reinfection. The Sertão region of Paraíba presents high prevalence of gastrointestinal helminthiasis among sheep, and the farm area is the most relevant risk factor for the development of these parasites.
\end{abstract}

Keywords: EPG, Haemonchus sp., semiarid, sheep, PCV.

\section{Resumo}

Objetivou-se determinar a prevalência e os fatores de risco para as helmintoses gastrintestinais, caracterizando o manejo sanitário sob fatores condicionantes das formas de controle dessas parasitoses em rebanhos de ovinos da região do Sertão da Paraíba. A pesquisa foi desenvolvida no período de abril a julho de 2012. Foram visitadas propriedades, utilizando-se 465 animais, sendo coletadas individualmente amostras de fezes e sangue durante as visitas. Em cada propriedade, foi aplicado questionário para a coleta de informaçôes acerca de variáveis que atuariam como possíveis fatores de risco. Observou-se que a prevalência das helmintoses gastrintestinais de ovinos na região do Sertão da Paraíba foi de $75,9 \%$. Pelo menos um animal foi positivo para essas helmintoses, em $53(98,1 \%)$ das 54 propriedades avaliadas. A análise de OPG (Ovos Por Gramas de Fezes) demonstrou que 51,8\% dos animais apresentaram infecção leve, 27,1\% infecção moderada, 9,9\% infecção pesada e 11,2\% infecção fatal. A utilização de anti-helmínticos ocorreu em 81,5\% das propriedades $(\mathrm{p}<0,05)$. O fator de risco mais relevante neste estudo foi a área da propriedade, porque delimita a área de pastejo do animal. Propriedades com muitos animais e pouca área de pastejo, que são as mais abundantes no Sertão da Paraíba, tendem a apresentar alta prevalência de helmintoses gastrintestinais, pois os animais estão mais propensos à reinfecção. A região do Sertão da Paraíba apresenta uma elevada prevalência de helmintoses gastrintestinais em ovinos, e a área das propriedades é o fator de risco mais relevante para o desenvolvimento dessas parasitoses.

Palavras-chave: OPG, Haemonchus sp., semiárido, ovinocultura, VG. 


\section{Introduction}

Sheep production is an economic activity conducted on almost all continents under various climates and types of vegetation, but it is of significant value only in some countries, and in most cases, it is developed empirically and extensively.

Brazil has a herd of more than 16.2 million sheep, and 56.8\% are concentrated in the northeastern region of the country. The state of Paraiba is ranked in fifth place, with 442,589 sheep. The Sertão region of Paraíba accounts for 84,092 animals (19\% of the state herd and $0.5 \%$ of the Brazilian herd) (IBGE, 2009).

Sheep farming in the semiarid region of northeastern Brazil is focused on meat and leather production and it is economically affected by high mortality rates, usually associated with gastrointestinal helminthiasis (LIMA et al., 2010b).

Disease severity, production losses and low productivity depend on the host's intensity of infection, immunity and nutritional status (STEAR et al., 2007). Young animals and pregnant females are more susceptible to helminths than are adult animals because of their delicate nutritional status and low immunity level (SILVA et al., 2009).

Indiscriminate use of anthelmintics is considered to be inefficient, costly and harmful to herds, since this favors rapid selection of parasites that are resistant to anthelmintics of different chemical groups, thereby hampering parasite control (MOLENTO et al., 2004).

Due to lack of studies that punctually investigate the epidemiological situation of parasitosis, several researches on the prevalence of gastrointestinal helminthiasis of small ruminants in Brazil have been erroneously carried out, where statistical treatments of sampling are not applied accordingly, generating deliberate misinformation. This study provides data, demonstrated by statistical models, on the prevalence and risk factors associated with gastrointestinal helminthiasis of sheep. Thus, we aimed to determine the prevalence and risk factors relating to gastrointestinal helminthiasis, and to characterize the sanitary management practiced among sheep herds in the Sertão region of the state of Paraíba state, based on factors that condition the ways of controlling these parasites in these herds.

\section{Materials and Methods}

The state of Paraiba is divided in four regions: Sertão, Borborema, Agreste, and Zona da Mata. This study was carried out in the Sertão region (Figure 1), which is formed by 83 municipalities grouped in seven micro-regions: Cajazeiras, Catolé do Rocha, Itaporanga, Patos, Piancó, Serra do Teixeira, and Sousa. This region comprises an area of $22,600.7 \mathrm{~km}^{2}$, accounting for $40.01 \%$ of the state area, with a population of 818,584 inhabitants. The climate is hot and dry, with average annual rainfall between 800 and $1200 \mathrm{~mm}^{3}, 32^{\circ} \mathrm{C}$ maximum temperature and $20^{\circ} \mathrm{C}$ minimum temperature, high rates of evaporation, and relative humidity around $70 \%$, with predominant secondary Caatinga biome (IBGE, 2009). According to Vilela et al. (2008), this region has a semi-arid climate, with a rainy season from January to May, when occurs an average of $98.6 \%$ of annual rainfall, and a dry season from June to December.

This study was conducted during the last two months of the rainy season (April and May) and the first and second months of the dry season (June and July). In this cross-sectional study, the sampling was designed to determine the prevalence of positive

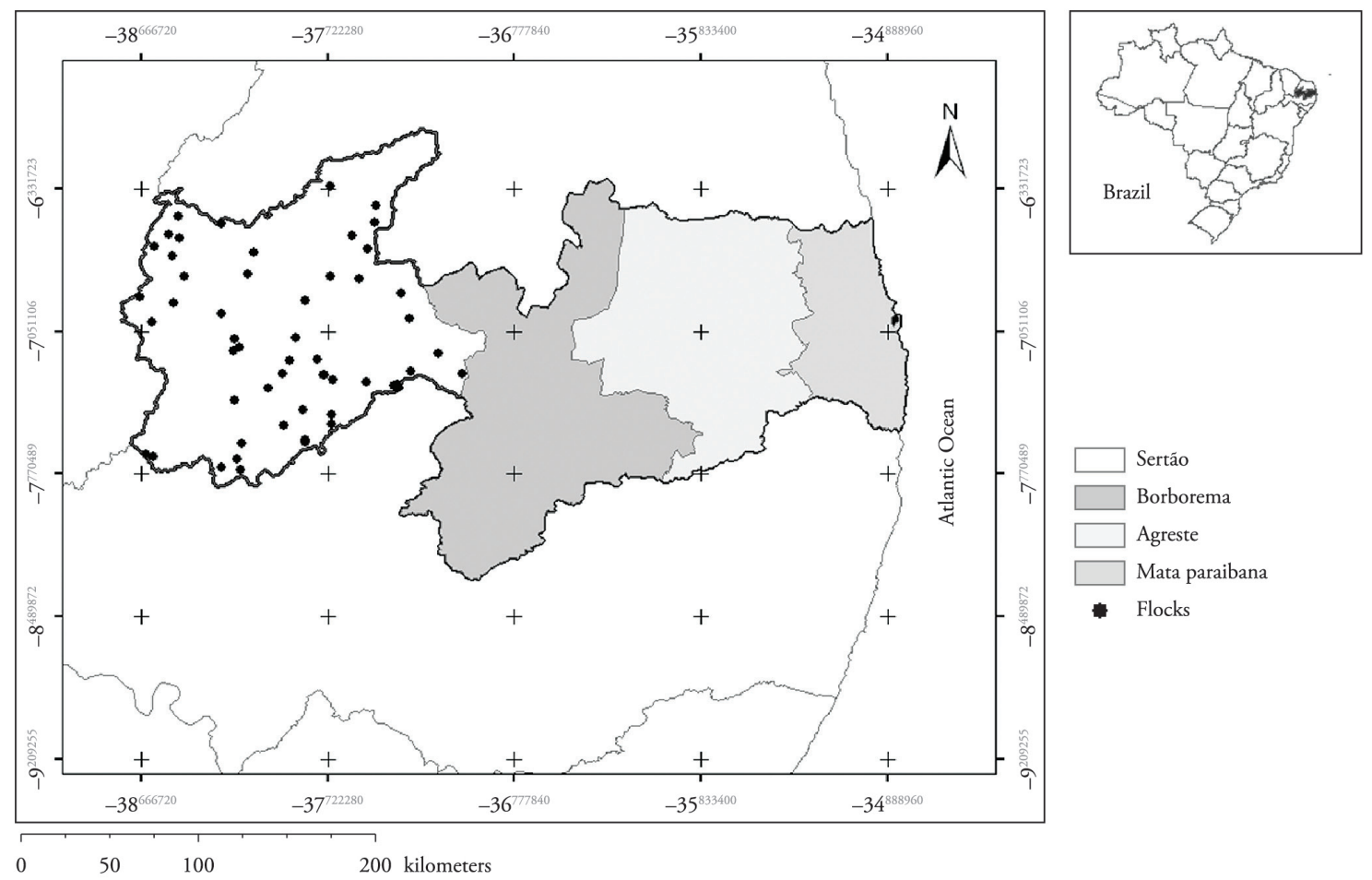

Figure 1. Georeferenced sheep farms from the Sertão region, Paraíba state, Brazil. 
farms (foci). The sampling was performed in two stages: (1) random selection of a predetermined number of farms (primary units); and (2) within the primary units, an established number of sheep was randomly sampled (secondary units).

The following parameters were considered to calculate the number of primary units to be sampled: (a) expected prevalence; (b) absolute error; and (c) confidence level, according to the formula for simple random samples (THRUSFIELD, 2007):

$$
\mathrm{n}=\frac{\mathrm{Z}^{2} \times \mathrm{P}(1-\mathrm{P})}{\mathrm{d}^{2}}
$$

In which:

$\mathrm{n}=$ number of sampled properties

$\mathrm{Z}$ = value of the normal distribution for confidence level of $95 \%$

$\mathrm{P}=$ expected prevalence of $82.76 \%$ (SANTOS et al., 2006)

$\mathrm{d}=$ absolute error of $5 \%$

In order to adjust it for finite populations, we used the following formula (THRUSFIELD, 2007):

$$
\mathrm{n}_{\text {ajus }}=\frac{\mathrm{N} \times \mathrm{n}}{\mathrm{N}+\mathrm{n}}
$$

In which:

$$
\begin{aligned}
& \mathrm{n}_{\text {ajus }}=\text { adjusted sample size } \\
& \mathrm{N}=\text { total population size } \\
& \mathrm{n}=\text { initial sample size }
\end{aligned}
$$

According to the IBGE (2009), this region has 8,293 sheep farms. Based on these data, the number of primary units to be visited was 54 . Then, the number of sheep to be selected was individually determined by herd to detect the presence of infection, using the following formula (THRUSFIELD, 2007):

$$
\mathrm{n}=\left[1-(1-\mathrm{p}) \frac{1}{\mathrm{~d}}\right] \times\left(\mathrm{N}-\frac{\mathrm{d}}{2}\right)+1
$$

In which:

$$
\begin{aligned}
& \mathrm{n} \text { - sample size } \\
& \mathrm{p} \text { - probability of detecting at least one infected animal } \\
& \mathrm{N} \text { - herd size } \\
& \mathrm{d} \text { - number of infected animals in the herd }
\end{aligned}
$$

The probability of finding at least one infected animal in the herd was determined by the confidence level of $95 \%(p=0.95)$, and the number of infected animals by herd (d) was calculated supposing intra-herd prevalence of $41.3 \%$ (AHID et al., 2008).

In total, 465 sheep from 54 farms were randomly sampled.

Blood and fecal samples were collected from each animal. Subsequently, the material was sent to the Domestic Animal Parasitic Diseases Laboratory of the Federal University of Campina Grande (UFCG), in Patos, Paraíba, Brazil.

The eggs per gram (EPG) concentration in feces was determined as described by Gordon \& Whitlock (1939), while fecal culturing was done in accordance with Roberts \& O'Sullivan (1950), using fecal sample pools from each farm. The packed cell volume (PCV) was determined individually for each blood sample, as described by Matos \& Matos (1988).
The helminths infection level was evaluated from the EPG values, using the following classification, as specified by Chagas et al. (2008): mild infection (EPG < 500); moderate infection (EPG 500 to 1500); heavy infection (EPG 1501 to 3000); and fatal infection (EPG > 3000).

Structured epidemiological questionnaires were conducted in all farms visited in order to collect information about variables that could act as potential risk factors for the development of gastrointestinal helminthiasis. The collected data were saved in electronic form, designed with the Microsoft Access software, and then used in the analysis of risk factors.

Pearson's correlation coefficient was calculated to check the possible correlations among the rate of Haemonchus sp., PCV, and EPG in animals, as well as the population density and EPG. For the comparison between the parasite load and PCV, the chisquare test or Fisher's exact test were used, with 5\% significance level (ZAR, 1999).

The data collected in the epidemiological surveys were used for the analysis of possible risk factors associated to the condition of property positive for endoparasites. A property was considered positive when at least one animal presented any level of infection. The analysis of risk factors was conducted in two steps: univariate analysis and multivariate analysis. In the univariate analysis, each independent variable was matched with the dependent one, and those that showed $p \leq 0.20$, by the chi-square test or Fisher's exact test, were selected for multivariate analysis by multiple logistic regression (HOSMER \& LEMESHOW, 2000). Significance level for multivariate analysis was $5 \%$. All analyses were performed by the SPSS 20.0 software, for Windows.

\section{Results}

The prevalence of sheep gastrointestinal helminthiasis in the Sertão region of the state of Paraíba was 75.9\% (353 animals). It was also observed that at least one animal tested positive for these helminthiasis on $53(98.1 \%)$ of the 54 farms evaluated.

The EPG analysis showed that $51.8 \%$ of the animals presented mild infection; $27.1 \%$, moderate infection; $9.9 \%$, heavy infection; and $11.2 \%$, fatal infection.

In correlating between the incidence of Haemonchus sp. and the PCV, regarding parasite development, it could be seen that the incidence of Haemonchus sp. increased as the animals' PCV decreased $(\mathrm{r}=-0.288, \mathrm{p}=0.035)$. A correlation between the incidence of Haemonchus sp. and the EPG was also observed $(\mathrm{r}=0.401, \mathrm{p}=0.003)$. There was a significant correlation between the EPG and the PCV $(r=-0.285, p=0.037)$. It was also noted that $99.1 \%$ of the animals with negative EPG presented $\mathrm{PCV} \geq 23$ and that $25.6 \%$ of the animals with EPG $>3000$ showed PCV $\leq 22$. This was statistically significant $(\mathrm{p}<0.05)$, meaning that the EPG increased as the PCV decreased (Figure 2).

In the larval cultures, the most prevalent helminth was Haemonchus sp. (79.9\%), followed by Strongyloides sp. (9.6\%), Trichostrongylus sp. (8.6\%), Oesophagostomum sp. (1.9\%), and Cooperia sp. (0.1\%).

Univariate analysis for risk factors is presented in Table 1. After logistic regression analysis, variables farm area ranging from 11 

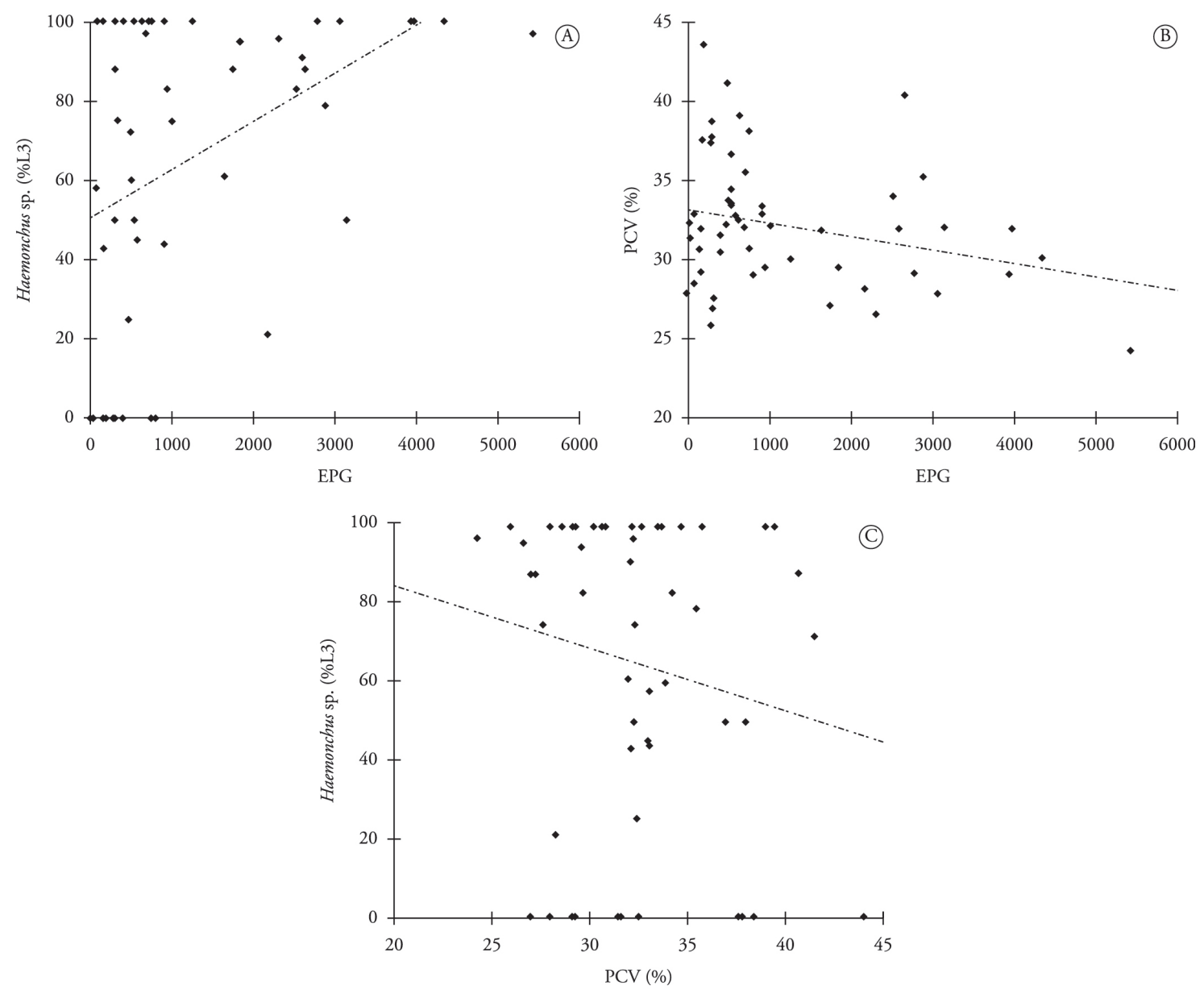

Figure 2. A - correlation graph between Haemonchus sp. (\% L3)/ EPG- Eggs Per Gram of feces, B - PCV (\%) - Packed Cell Volume/ EPG, and C - Haemonchus sp. (\% L3)/ PCV (\%).

to 25 ha (odds ratio $=19.1 ; 95 \% \mathrm{CI}=4.0-90.3 ; \mathrm{p}<0.001)$ and anthelmintic use (odds ratio $=2.6 ; 95 \% \mathrm{CI}=1.3-5.2 ; \mathrm{p}<0.005$ ) were identified as risk factors.

Regarding the anthelmintic strategy, it was found that, in $16.6 \%$ of the farms, anthelmintics were administered three times a year: at the beginning and end of the rainy season and during the dry season. Deworming was done every month on $9.3 \%$ of the farms and it was done after clinical signs had been observed on $20.3 \%$ of them. Anthelmintics were used on $81.5 \%$ of the farms.

On $94.9 \%$ of the farms studied, which ranged in area from 11 to $25 \mathrm{ha}$, at least one animal tested positive for helminthiasis. These areas were more likely to present occurrences of these parasites.

The calculation of sheep population density revealed that the smaller the area and the greater the number of grazing animals were, the higher the parasite burden also was. This was statistically significant for occurrence of gastrointestinal parasites $(p<0.05)$.

There was a correlation between the sheep density variable (number of animals in relation to the grazing area) and the EPG $(\mathrm{r}=-0.281, \mathrm{p}=0.039)$, such that the lower the density was, the larger the EPG was (Figure 3).

The producers' expenses on purchases of anthelmintic products were estimated based on information such as the active agent used (drug), number of times that the compound was administered to the animals, number of sheep per farm and market commercial value. Thus, these producers in the state of Paraíba were spending approximately US\$231,000.00/year on purchases of anthelmintics and those in the Sertão region were spending around US\$ 43,800.00/year.

\section{Discussion}

The prevalence of sheep gastrointestinal helminthiasis in the Sertão region of the state of Paraíba was $75.9 \%$. This was in agreement with Ahid et al. (2008), who reported that gastrointestinal parasites were present in $75.2 \%$ of the sheep in the western region of the state of Rio Grande do Norte, but in disagreement with Silva et al. (2010), who observed a parasite frequency of $94.5 \%$ among sheep in Rondonopolis, state of Mato Grosso.

We found that the prevalence of farms with at least one animal positive for gastrointestinal parasites was $98.1 \%$, thus corroborating Lima et al. (2010a), who reported that infected animals were present on $100 \%$ of the farms in a study carried out in the state of Pernambuco, Brazil. 
Table 1. Univariate analysis on herd and farm characteristics relating to risk factors for development of sheep gastrointestinal helminthiasis in the Sertão region of the state of Paraíba, Brazil.

\begin{tabular}{|c|c|c|c|c|c|}
\hline Variables & Category & $\begin{array}{c}\text { Number of farms } \\
(\%)\end{array}$ & $\begin{array}{c}\text { Total number of } \\
\text { animals }\end{array}$ & $\begin{array}{c}\text { Number of positive } \\
\text { animals }(\%)\end{array}$ & $\mathbf{p}$ \\
\hline \multirow[t]{2}{*}{ Sex } & Male & - & 107 & $89(83.2)$ & \\
\hline & Female & - & 358 & $264(73.7)$ & $0.061^{*}$ \\
\hline \multirow[t]{3}{*}{ Age (months) } & $<12$ & - & 190 & $146(76.8)$ & \\
\hline & $13-36$ & - & 234 & $177(75.6)$ & \\
\hline & $>36$ & - & 41 & $30(73.2)$ & 0.875 \\
\hline \multirow[t]{7}{*}{ Anthelmintic strategy } & Every 6 months & $13(24)$ & 90 & $60(66.7)$ & \\
\hline & Every 4 months & $9(16.7)$ & 91 & $78(85.7)$ & \\
\hline & Once a year & $2(3.7)$ & 17 & $14(82.4)$ & \\
\hline & Clinical signs & $11(20.3)$ & 118 & $94(79.7)$ & \\
\hline & Every 30 days & $5(9.3)$ & 21 & $18(85.7)$ & \\
\hline & Every 15 days & $3(5.6)$ & 54 & $40(74.1)$ & \\
\hline & No & $10(18.5)$ & 68 & $46(67.6)$ & $0.230^{*}$ \\
\hline \multirow[t]{2}{*}{ Anthelmintic use } & No & $10(18.5)$ & 71 & $48(67.6)$ & \\
\hline & Yes & $43(81.5)$ & 394 & $305(77.4)$ & $0.104^{*}$ \\
\hline \multirow[t]{4}{*}{ Active agent rotation } & On each occasion used & $6(11.1)$ & 63 & $55(87.3)$ & \\
\hline & According to price & $3(5.6)$ & 32 & $20(62.5)$ & \\
\hline & Sporadically & $20(37)$ & 176 & $140(79.5)$ & \\
\hline & None & $25(46.3)$ & 194 & $138(71.1)$ & $0.010^{*}$ \\
\hline \multirow[t]{5}{*}{ Farm area (ha) } & $<10$ & $17(31.5)$ & 120 & $92(76.7)$ & \\
\hline & $11-25$ & $5(9.3)$ & 39 & 37 (94.9) & \\
\hline & $26-50$ & $9(16.6)$ & 88 & $74(84.1)$ & \\
\hline & $51-100$ & $13(24.1)$ & 123 & $98(79.7)$ & \\
\hline & $>100$ & $10(18.5)$ & 95 & $52(54.7)$ & $0.000^{*}$ \\
\hline \multirow[t]{5}{*}{ Number of sheep } & $<10$ & $18(33.3)$ & 84 & $59(70.2)$ & \\
\hline & $11-30$ & $18(33.3)$ & 184 & $153(83.2)$ & \\
\hline & $31-60$ & $13(24.1)$ & 152 & $107(70.4)$ & \\
\hline & $61-100$ & $4(7.4)$ & 32 & $22(68.8)$ & \\
\hline & $>100$ & $1(1.9)$ & 13 & $12(92.3)$ & $0.017^{*}$ \\
\hline
\end{tabular}

*Variables used in multivariate analysis $(\mathrm{p} \leq 0.20)$.

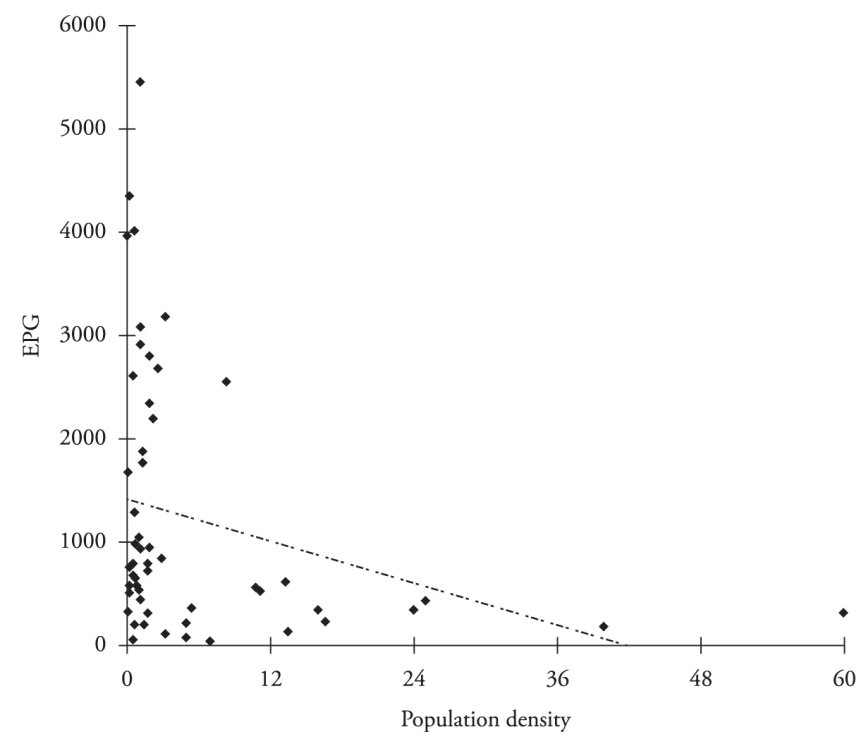

Figure 3. Graph of dispersion between EPG (Eggs Per Gram of feces) and population density of sheep in the Sertáo region of Paraíba State.
It was found that $51.8 \%$ of the animals showed mild infection and $11.2 \%$ presented fatal infection, in disagreement with Ahid et al. (2008), who observed that $72.2 \%$ of the animals showed mild infection and only $1.3 \%$ had fatal infection. Silva $\&$ Fonseca (2012) found that $35 \%$ of the animals presented mild infection and $25 \%$ had fatal infection in the state of Rio de Janeiro.

It was observed that $99.1 \%$ of the animals that were negative for eggs presented $\mathrm{PCV} \geq 23$ and that $25.6 \%$ of the animals with EPG > 3000 showed PCV $\leq 22$. Molento et al. (2004) reported that findings of this nature suggested that some animals had the ability to withstand high parasitic burdens, which they termed resistant animals, while others succumbed to helminthic infections, which they termed susceptible animals.

In evaluating the correlation between the incidence of Haemonchus sp. and the PCV, we noted that this rate increased as the animals' PCV decreased $(\mathrm{r}=-0.288, \mathrm{p}=0.035)$. Vilela et al. (2012) observed a positive correlation between these variables in a study on dairy goats in the semiarid region of northeastern Brazil. Thus, it can be stated that when an animal presents high 
prevalence of Haemonchus sp. larvae, anemia is triggered due to hematophagous action.

There was also a correlation between the prevalence of Haemonchus sp. and the EPG $(\mathrm{r}=0.401, \mathrm{p}=0.003)$. The correlation between these variables was substantial and significant when the occurrence this parasite was high in larval cultures, as found in the present study. In these instances, there was massive production of eggs, which were shed in the feces, thereby increasing the EPG. On the other hand, Cringoli et al. (2009) conducted a study on dairy sheep in Italy and did not find any correlation between these variables.

The most prevalent helminth genus was Haemonchus sp. (79.9\%), thus corroborating Vilela et al. (2009), who also found that Haemonchus sp. (81\%) was the most prevalent genus in sheep in the Sertáo region of Paraíba. Sczesny-Moraes et al. (2010), in the state of Mato Grosso do Sul, and Mbuh et al. (2008), in the Bokova region, Cameroon, also found similar results.

It was observed that $20.3 \%$ of the owners dewormed their animals when there were apparent clinical sings of the disease, which is an excellent alternative for minimizing the resistance to anthelmintics. This action results in the presence of animals with adult parasites that do not receive chemical treatment, leaving a portion of the worm population in refugia. Costa et al. (2011) reported that the size of the population involved played a fundamental role in maintaining the effectiveness of the drugs, thereby delaying the selection process. During the dry season, helminths remained in the host, because this way they avoided adverse weather. Thus, they continued in a sexually immature stage until they were presented with favorable environmental conditions for their development (CARVALHO et al., 2011).

Anthelmintics were used on $81.5 \%$ of the farms. This variable was identified as risk factor and corroborated Alencar et al. (2010), who reported that $88.2 \%$ of the producers used anthelmintics to combat worms in small ruminants in the Sertão region of the state of Pernambuco.

Calculation of the sheep population density revealed that the smaller the area and the greater the number of grazing animals were, the higher the parasite burden was, and this was statistically significant for occurrences of gastrointestinal parasites. The animal population density observed in this study was high, with a profile of semi-extensive rearing on small areas of native pasture. This was yet another factor in the higher incidence of helminths, because this pasture had no rest period and the animals were turned out to graze in the same area every day.

It was noted that the number of animals on the farms influenced the development of helminthiasis, such that the prevalence of infected animals was $92.3 \%$ in herds with more than 100 animals. Hoste et al. (2002) suggested that a small number of animals in the herd exhibited high levels of excretion of the eggs that are responsible for contamination of pastures.

There was a correlation between sheep population density and the EPG $(r=-0.281, p=0.039)$. This correlation was significant, because the greater the number of animals grazing in a small area was, the greater the number of eggs excreted was and the greater the chances of infection and reinfection of the animal population were. Although this practice is not economically viable for producers, animal contamination due to nematodes can be significantly reduced when these animals are raised under low-density conditions (RAMOS et al., 2004).

The most important risk factor in the present study was the farm area: farms with areas ranging from 10 to 25 ha were 19.1 times more likely to have parasitized animals. This was the most important risk factor because it defined the animal grazing area. Farms with many animals and little pasture area are the most abundant type of farm in the Sertão region of the state of Paraíba and this situation may influence the rate of pasture infestation with nematodes and the higher animal reinfection rate, thus explaining the high helminth prevalence in sheep.

Duarte et al. (2012) observed that properties with a pasture area of 30 ha, low stocking rate and, consequently, low population density, presented less risk of contamination by parasites.

The expenditure on anthelmintic drugs in the Sertâo region was approximately US\$ 43,800.00 per year. Lima et al. (2010b), Costa et al. (2006) and Vieira et al. (2008) reported that the expenditure on these anthelmintics was threatening small ruminant production in some regions such as northeastern Brazil and endangering other areas of greater animal production. Indiscriminate and misguided use of these drugs causes increased market cost and produces results below expectations. Hence, new ways to control helminths in small ruminants have been widely tested, such as using phytotherapy, the Famacha ${ }^{\odot}$ method and nematophagous fungi. These alternatives need to provide the lowest possible environmental impact and have a low cost for producers, since this Brazilian region is worked by producers of low socioeconomic status, with no technical training, who are unable to invest in facilities. These expenditures could be redirected towards investments in their farms and herds, and towards improving their quality of life.

\section{Conclusion}

The Sertão region of the state of Paraíba presents high prevalence of gastrointestinal helminthiasis in sheep. The farm area is the most relevant risk factor for development of these parasites.

\section{References}

Ahid SMM, Suassuna ACD, Maia MB, Costa VMM, Soares HS. Parasitos gastrintestinais em caprinos e ovinos da região Oeste do Rio Grande do Norte, Brasil. Ciênc Anim Bras 2008; 9(1): 212-218.

Alencar SP, Mota RA, Coelho MCOC, Nascimento SA, Abreu SRO, Castro RS. Perfil sanitário dos rebanhos caprinos e ovinos no Sertáo de Pernambuco. Ciênc Anim Bras 2010; 11(1): 131-140.

Carvalho CD, Moreira FRO, Bezerra KS, Guimarães JVCN, Cardoso JC, Lima AL, et al. Infecçáo parasitária e perfil sanitário de plantel caprino em área urbana de Sergipe. Scientia Plena 2011; 7(3): 1-9.

Chagas ACS, Oliveira MCS, Esteves SN, De Oliveira HN, Giglioti R, Giglioti C, et al. Parasitismo por nematóides gastrintestinais em matrizes e cordeiros criados em São Carlos, São Paulo. Rev Bras Parasitol Vet 2008;17(1): 126-132. PMid:20059831.

Costa CTC, Bevilaqua CML, Maciel MV, Camurça-Vasconcelos ALF, Morais SM, Monteiro MVB, et al. Anthelmintic activity of Azadirachta 
indica A. Juss against sheep gastrointestinal nematodes. Vet Parasitol 2006 137(3-4): 306-310. http://dx.doi.org/10.1016/j.vetpar.2006.01.002. PMid:16517074

Costa VMM, Simões SVD, Riet-Correa F. Controle das parasitoses gastrintestinais em ovinos e caprinos na regiáo semiárida do Nordeste do Brasil. Pesqui Vet Bras 2011; 31(1): 65-71. http://dx.doi.org/10.1590/ S0100-736X2011000100010

Cringoli G, Rinaldi L, Veneziano V, Mezzino L, Vercruysse J, Jackson F. Evaluation of targeted selective treatments in sheep in Italy: effects on faecal worm egg count and milk production in four case studies. Vet Parasitol 2009; 164(1): 36-43. http://dx.doi.org/10.1016/j. vetpar.2009.04.010. PMid:19411140

Duarte ER, Silva RB, Vasconcelos VO, Nogueira FA, Oliveira NJF. Diagnóstico do controle e perfil de sensibilidade de nematódeos de ovinos ao albendazol e ao levamisol no norte de Minas Gerais. Pesqui Vet Bras 2012; 32(2): 147-152.

Gordon HM, Whitlock HV. A new tecnique for counting nematode eggs in sheep faeces. J Counc Sci Ind Res 1939; 12(1): 50-52.

Hosmer DW, Lemeshow S. Applied logistic regression. 2nd ed. New York: John Wiley e Sons; 2000. http://dx.doi.org/10.1002/0471722146.

Hoste H, Le Frileux Y, Goudeau C, Chartier C, Pors I, Broqua C, et al. Distribution and repeatability of nematode faecal egg counts in dairy goats: a farm survey and implications for worm control. Res Vet Sci 2002; 72(3): 211-215. http://dx.doi.org/10.1053/rvsc.2002.0546. PMid:12076116

Instituto Brasileiro de Geografia e Estatística - IBGE. Epi Info [online]. 2009 [cited 2012 Mar 08]. Available from: http://www.ibge.gov.br.

Lima MM, Farias MPO, Romeiro ET, Ferreira DRA, Alves LC, Faustino MAG. Eficácia da moxidectina, ivermectina e albendazole contra helmintos gastrintestinais em propriedades de criação caprina e ovina no Estado de Pernambuco. Ciênc Anim Bras 2010a; 11(1): 94-100.

Lima WC, Athayde ACR, Medeiros GR, Lima DASD, Borburema JB, Santos EM, et al. Nematóides resistentes a alguns anti-helmínticos em rebanhos caprinos no Cariri Paraibano. Pesqui Vet Bras 2010b; 30(12): 1003-1009. http://dx.doi.org/10.1590/S0100-736X2010001200001.

Matos MS, Matos PF. Laboratório clínico médico veterinário. 2nd ed. Rio de Janeiro: Atheneu; 1988.

Mbuh JV, Ndamukong KJN, Ntonifor N, Nforlem GF. Parasites of sheep and goats and their prevalence in Bokova, a rural area of Buea Sub Division, Cameroon. Vet Parasitol 2008; 156(3-4): 350-352. http:// dx.doi.org/10.1016/j.vetpar.2008.06.021. PMid:18707810

Molento MB, Tasca C, Gallo A, Ferreira M, Bononi R, Stecca E. Método Famachacomo parâmetro clínico individual de infecção por Haemonchus contortus em pequenos ruminantes. Ciênc Rural 2004; 34(4): 1139-1145. http://dx.doi.org/10.1590/S0103-84782004000400027.

Ramos CI, Bellato V, Souza AP, Avila VS, Coutinho GC, Dalagnol CA. Epidemiologia das helmintoses gastrintestinais de ovinos no planalto catarinense. Ciênc Rural 2004; 34(6): 1889-1895. http://dx.doi. org/10.1590/S0103-84782004000600034.

Roberts FHS, O'Sullivan JP. Methods for egg counts and larval cultures for strongyles infesting the gastrointestinal tract of cattle. Aust J Agric Res 1950; 1(1): 99-102. http://dx.doi.org/10.1071/AR9500099.

Santos WB, Ahid SMM, Suassuna ACD. Aspectos epidemiológicos da caprinocultura e ovinocultura no munícipio de Mossoró (RN). Hora Vet 2006; 26(152): 25-28.

Sczesny-Moraes EA, Bianchin I, Silva KF, Catto JB, Honer MR, Paiva F. Resistência anti-helmíntica de nematóides gastrintestinais em ovinos, Mato Grosso do Sul. Pesqui Vet Bras 2010; 30(3): 229-236. http://dx.doi. org/10.1590/S0100-736X2010000300007.

Silva AR, Araújo JV, Braga FR, Frassy LN, Tavela AO, Carvalho RO, et al. Biological control of sheep gastrointestinal nematodiasis in a tropical region of the southeast of Brazil with the nematode predatory fungi Duddingtonia flagrans and Monacrosporium thaumasium. Parasitol Res 2009; 105(6): 1707-1713. http://dx.doi.org/10.1007/s00436-009-16138. PMid:19756749

Silva JB, Fonseca AH. Suscetibilidade racial de ovinos a helmintos gastrintestinais. Semina: Ciênc Agrár 2012; 32(S1): 1935-1942.

Silva MRL, Sousa EA, Bonelli EA, Medeiros MO, Silva GF, Queiroz EO. Parasitas gastrintestinais de ovinos criados na região de RondonópolisMT. Rev Biod 2010; 9(1): 67-73.

Stear MJ, Doligalska M, Donskow-Schmelter K. Alternatives to anthelmintics for the control of nematodes in livestock. Parasitology 2007 134(2): 139-151. http://dx.doi.org/10.1017/S0031182006001557. PMid:17076922

Thrusfield M. Veterinary Epidemiology. 3rd ed. Oxford: Blackwell Science; 2007

Vieira LS. Métodos alternativos de controle de nematóides gastrintestinais em caprinos e ovinos. Tecn Ciênc Agropec 2008; 2(2): 49-56.

Vilela VLR, Feitosa TF, Linhares EF, Athayde ACR, Molento MB, Azevedo SS. FAMACHA(C) method as an auxiliary strategy in the control of gastrointestinal helminthiasis of dairy goats under semiarid conditions of Northeastern Brazil. Vet Parasitol 2012; 190(1-2): $281-$ 284. http://dx.doi.org/10.1016/j.vetpar.2012.05.024. PMid:22726386

Vilela VLR, Feitosa TF, Lôbo KMS, Bezerra DAC, Athayde ACR Potencial anti-helmíntico da raiz de Solanum paniculatum Linnaeus (1762) em ovelhas do Semi-árido Paraibano. Acta Vet Bras 2009; 3(1) 20-24.

Vilela VLR, Solano GB, De Araújo MM, De Sousa RV, Da Silva WA, Feitosa TF, et al. Ensaios preliminares para validaçáo do método FAMACHA@ em condições de Semi-Árido Paraibano. Rev Bras Parasitol Vet 2008;17(1): 154-157. PMid:20059836.

Zar JH. Biostatistical analysis. 4th ed. Upper Saddle River: Prentice Hall; 1999. 


\section{Brazilian Journal of Veterinary Parasitology}

ISSN 1984-2961 (Electronic)

www.cbpv.org.br/rbpv

Braz. J. Vet. Parasitol., Jaboticabal, v. 27, n. 4, p. 614-614, oct.-dec. 2018

Doi: https://doi.org/10.1590/S1984-296120180077

\section{ERRATUM}

In the article "Sheep gastrointestinal helmithiasis in the Sertâo region of Paraíba State, Northeastern Brazil: prevalence and risk factors”, DOI: http://dx.doi.org/10.1590/S1984-29612014089, published in issue 4, volume 23, 2014, the Brazilian Journal of Veterinary Parasitology, on page 490, which reads:

$$
\mathrm{n}=\left[1-(1-\mathrm{p}) \frac{1}{\mathrm{~d}}\right] \times\left(\mathrm{N}-\frac{\mathrm{d}}{2}\right)+1
$$

Read up:

$$
\mathrm{n}=\left\{1-\left(1-\mathrm{p}_{1}\right)^{1 / \mathrm{d}}\right\}\{\mathrm{N}-\mathrm{d} / 2\}+1
$$

